\title{
The Application of Ecological Element in the Landscape Design of Campus Roof Garden
}

\author{
Wenjun Wang \\ City College of WUST, Wuhan, China \\ 15827425957@163.com
}

Keywords: College Campus; Roof Garden; Ecological Element

\begin{abstract}
This paper based on the research of the ecological element in the landscape design of campus roof garden. Using the related theory of city planning, campus planning and behavioral psychology theory combined with the basic design principle of buildings on campus roof space, put forward the design proposal of building roof space reasonable use in colleges and universities. According to the study on the conditions and rationalization of the roof space of university buildings make reasonable suggestions to against the shrinking campus space and low utilization rate of roof space of campus buildings. The paper is in response to the national strategic planning on green campus and ecological campus and has good theoretical research and practical application value.
\end{abstract}

\section{Introduction}

College campus as a place for shaping young students' outlook on life and values, needs to create a good material and spiritual environment for students. However, enrollment expansion, the campus land stress constantly emerging, and the shortage of education resources phenomenon in campus does not have enough space, further development students' daily life and learning, the lack of communication, have a rest and exercise space, therefore, extensive and reasonable use of campus roof space, it is necessary, also is inevitable.

Respond to a nation puts forward "to promote green development, the development cycle, low carbon development", "national sustainable development", earnestly carry out the green campus, the study of ecological campus and construction work. In today's constantly promoting urbanization, land space and the subsequent development of colleges and universities is relatively small, at the same time, the school teachers and students of communication, space occupation by enlarging the parking, so the reasonable development and utilization of the top surface of the space research has important theoretical and practical significance.

On the one hand, it is necessary to deal with the rationalization and utilization of the roof space of university buildings, so as to avoid the unpractical design such as participatory, interactive and weak practicability. On the other hand, we should deal with the problems of design and implementation and avoid the appearance of "theoretical" design. The design should have strong practicability. In order to realize the development strategy of green campus and ecological campus, the school has distinct characteristics, and meanwhile, the campus space is expanded, and various functional Spaces are more complete and reasonable.

\section{Current Situation and Problems}

Current Situation. In colleges and universities in our country at present, many colleges and universities lack of larger green. In the planning of the campus, is still part of the planning and design units to take "building first, green fill" mode, this leaves green space is relatively limited. We should improve the quality of campus environment, the height of reserve in the campus planning of large-area greening area, for centralized landscaped. Large (larger) green land of campus landscape environment will produce important influence on. And some of the smaller the role of green space also can't be ignored, they have the sense of the landscape ecology "pedal" 
function. In the limited green space should be multi-level three-dimensional green, give full play to the potential of green space to improve the environment.

Problems. Through investigation and examination, the following problems are commonly found in college campuses: the amount of three-dimensional green is insufficient and the ecological benefits are not high, season photograph is not outstanding, ornamental theme is not distinct, the characteristics of regional greening are not obvious, and the identification of campus greening is poor and lack of campus cultural connotation.

\section{Solutions}

Garden Road. The gardens are particular about winding paths and seclusion, making people feel as if they are in the nature. This is also the effect that the roof garden with extremely limited space should achieve. Good garden design is the design of the space, in the distant view is a fine piece of art, entered the later visit which make people linger, each entry has comments, as if to consider. In order to achieve such a requirement, it is necessary to speculate the tourists' psychology and use the garden road to divide the space, so as to guide the tour route. Simply put, the roof garden should make the best use of the limited space, so that tourists have access to the road, the scenery is considerable. The garden road should be designed as a circular loop, and the main garden road should avoid dead roads. The main garden road is responsible for connecting various small scenic spots of the roof garden. The secondary garden road can guide people to more private areas, such as the pavilion chair resting place. Meanwhile, it should be noted that the garden road should not be too close to the edge of the roof to prevent tourists from accidents.

The Water. The water scene in the roof garden can be divided into moving water and still water. As the name suggests, the dynamic water refers to water can flow, or the fountain, needs to be considered in setting up dynamic water to the voice of the water, does not make too much noise in pursuit of landscape effect, general dynamic water's position is the center of the roof garden, can attract the most attention. The setting of still water is to foil a kind of halcyon and peaceful atmosphere commonly, here is the place that gives human body breath or think meditation.

The waterproof of modern roof is still an important problem. If there is leakage, it will bring great trouble to the residents. In terms of load, the density of water is not high, only half of the planting soil, but the ability to hold the density of water without special cement leakage was about 2.5 times of the density of water. Therefore, if there is no special demand for water, the water in the roof garden should be set very carefully, usually in a small area of water, so as to stop at any point.

Plant. Plants have regional differences, different plants have different habits of the location, so usually grow native plants in landscape design, otherwise it need to spend a lot of manpower and maintenance. Because the roof garden is located at high altitude, it has a stronger wind rating than the ground, so it needs higher wind resistance of plants, and some plants need to set up separate support frames. Due to the limited load bearing capacity of roof garden, the planting matrix is much thinner than the ground, so the plants with shallower roots are required. In addition, some plants such as meadow, according to the tree and so on in order to absorb more moisture in the soil, has a strong aggressive, easy to damage the roof garden of the waterproof layer and root layer, so should avoid to use.

On the collocation of plant kind should accomplish 4 seasons evergreen, 4 seasons have flower, such whenever somebody enters housetop garden to be able to enjoy green, feel the change of driver at the same time. Fallen leaves and ripe fruits of plants may increase the need for manual maintenance and should be avoided if roof gardens are expected to be of low maintenance intensity.

Safety. The security principle should come first. A rooftop garden is the biggest characteristic is to build on buildings, some even are high in the sky, different from traditional green space can be stabilized by the earth, and the roof garden can only be attached to the building, if improper roof garden design, easy to damage even collapse building. Therefore, it is necessary to strictly calculate the load that the roof can withstand, whether it is to reconstruct the common roof or design the roof garden synchronously. In addition to the most basic load, the landscape design of the roof garden and the design of the garden road should also be carefully considered, so as to avoid the accident of 
the roof falling into the deep part of the garden. High guardrails should be built at the edge of the building. The rails should be more closely spaced than ordinary railings to prevent children or animals from crowding the rails and accidents.

On the choice of plant category, also should avoid to rapid growth of tall trees, or in planting trees, can meet the demand of roof load, but in a few years but will crush the roof, to reduce the supply of fertilizer, plant nutrition surplus some big branches should be cut. Shrubs and plants should be non-spiny to avoid scratching visitors. Plant roots should also avoid choosing varieties that can easily Pierce roof aquifers.

Functions. The roof garden is attached to the building and should be designed according to the needs of the users in the building. And due to the narrow roof construction site, unlike traditional garden can in order to meet a wide range of audience and the area of design is very big, therefore, roof garden has set a main function.

Greening plants have release oxygen, purify air, adjust the temperature and humidity, sound insulation noise reduction and other ecological function. The campus of teachers and students to study and work need good environment to keep the head of the flexible, keep the air fresh is very important. According to the abroad study, if each person can have 10 square meters in the city forest or 23 square meters of lawn, can automatically adjust the proportion of carbon dioxide and oxygen in the air, make the air fresh.

Regional. Regional landscape should reflect the ecological principle, which is mainly from the perspective of natural factors. Different regions have different natural conditions, so it is necessary to take local environment into consideration in landscape design, that is, local ecological environment should not be damaged. Compared with western gardens, which attach importance to the transformation of the natural environment according to people's will, traditional Chinese gardens are more inclined to respect nature. "although made by people, the sky turns into the sky" is one of the design concepts. It can be seen from this simple "ecological" design principle.

Spiritual needs. Nowadays, social competition is becoming increasingly fierce, which accelerates people's life pace and makes them highly nervous in work and study. If in university teaching building roof opening a multifunctional area, the teachers and students into a green environment can not only enjoy the beautiful scenery, and can breathe fresh air, will inevitably make accumulate over a long period of psychological pressure to get maximum release. Roof greening conforms to this demand precisely, it moves the ground greening to the building roof surface to eliminate the work fatigue, the alleviation study psychology pressure and so on has the better adjustment function.

Green reflected light can stimulate people's physical vigor, make people mentally feel calm. And green makes the person feels comfortable, can regulate the nervous system, in the trees were green space, can make to reduce and eliminate eye fatigue, especially for more knowledge workers with the eye, such as students, teachers, and science and technology workers.

Cultural. Campus green space is the second class of learning, communication between teachers and students, for teachers and students to provide a good communication, exercise, learning, entertainment and leisure places. At the same time, the campus green space is the embodiment of the campus culture and aesthetic temperament and interest. The university teachers and students have higher aesthetic taste and art appreciation level, built the campus green space is a combination of cultural and artistic quality of high quality environment, can be able to view, environmental education.

Economic. From the perspective of saving urban land resources, compared with urban green space, roof garden can be said to be zero cost. So roof gardens have saved more than half of the money spent on land purchases compared with urban green Spaces. But from the perspective of terrain design, plant selection and labor cost, the cost per unit area of roof garden is higher. First of all, the design cost of roof garden is higher than that of traditional garden, because it involves not only landscape design but also structural design. Secondly, roof garden needs special soil materials and artificial substrates. Although the cost of artificial substrates has been greatly reduced with the development of technology, it is still far higher than "free" natural soil. The artificial cost, one each 
in the roof garden, each plant needs to the roof from the ground, it is time-consuming to engineering, also need more frequently in after the completion of the roof garden artificial maintenance, otherwise, they need to pay a higher cost of "maintenance". Therefore, in the initial design stage of roof garden, we need to consider the cost from the perspective of the whole life cycle.

Facilities. If the rockery model is used in the roof garden, only small and light mountain models can be used, and the topography can only make small ups and downs with the permission of the roof bearing capacity. Summerhouses are common in landscape facilities, but they only appear in intensive roof gardens. Due to the small space, the scale of pavilion is also small, usually only a few people can rest together in the pavilion.

The style of the chair should reflect the style of the roof garden. If it is a Chinese garden, it will adopt the Chinese style of the chair. If it is a European style garden, it will adopt the European style of the chair. The seats should be arranged rhythmically according to the direction of the garden road, and the garbage cans should be the same. Other landscape facilities, such as lighting fixtures and sprinkler systems, should be identified at the design stage, otherwise it would be difficult and expensive to redesign later. Different lamps and lanterns has different division of labor, such as a purely night in charge of lighting lamps and lanterns, but also some lamps and lanterns is responsible for the foil atmosphere, some lamps and lanterns is attached to the outline shape on landscape facilities, increase performance effect at night. In the meantime, lamps and lanterns still have the characteristic that divides landscape space, guide visitor to tour route, if ground lamp.

\section{Conclusion}

With the development of campers, problems such as shortage of campus land area and shortage of education resources keep emerging. It is very necessary and imperative to make full use of the roof space resources of campus teaching buildings. As a low energy consumption and high efficiency construction method, roof garden has become a kind of life appeal of modern people, and its construction and development are bound to bring the improvement of people's life quality.

On the premise of meeting the requirements of the roof garden of teaching buildings in colleges and universities, increasing the green coverage index in the campus will certainly bring about great business opportunities in greening related industries. Despite many conditions that limit the development of the colleges and universities, but as people living standard rise and the transformation of consciousness, relevant government policies and regulations, the university teaching building roof garden as a yet to be further development and utilization of "resource", is bound to get some attention and protection.

\section{Acknowledgement}

The research topic of City College of WUST 2017, Sky campus -- rationalization and research of roof space of university buildings. Item number:2017CYYBKY011.

\section{References:}

[1] H.L. Liu: Humanization Design and Application Research of Roof Garden in Guangzhou (MS., South China University of Technology, China 2016), p.8.

[2] Y.B.Chen: Green Campus (China Architecture \& Building Press, China 2012), p.86.

[3] T. Lin: A Study on Landscape Model and Construction Technique of prefabricated roof garden (MS., Zhongkai University of Agriculture and Engineering, China 2014), p.17.

[4] Shao Danjin. Research on Design Method in Chinese Traditional Garden Planting [D].Beijing: Beijing Forestry University,2012,16(16):110-114.

[5] D.K. Tao, J. Xia, Y.C. Guo: Huazhong Architecture, Vol.24(2014) No.6, p.118.

[6] Sun Xuehen. Planning and Design of Plant Landscape [M].The first edition. Beijing: China 
Forestry Publishing House, 2012.

[7] T.T. Liu, J. Dan, Q.Z. Li: Modern Landscape Architecture, Vol.12(2015) No.7, p.910.

[8] Hao Peiyao, Li Guanheng, Yin Hao, etc. Study on Optimization of Course Organization in "Garden Plant Landscape Planning" of Beijing Forestry University [J].Forestry Education in China,2015,33(1):68-70.

[9] Clare Cooper, Carolyn Francis: People Places Design Guidelines for Urban Open Space (China Architecture \& Building Press, China 2001), p.183.

[10] W.M.Zhao: Theory and Method of Mountain University Campus Planning (Huazhong University of Science \& Technology Press , China 2007), p.68.

[11] J.H. Wu: China Building Waterproofing, 2015 No.15, p.13.

[12]X.M. Wang: Roof Garden Design and Case Study (Phoenix Science Press, China 2013), p.130. 